\title{
DUKUNGAN KELUARGA PADA ORANG DENGAN HIV/AIDS (ODHA) : A LITERATURE REVIEW
}

\section{Family Support in Patients Living with HIVI AIDS (PLWHA): A Literature Review}

Ady Irawan. AM ${ }^{1}$, Titih Huriah ${ }^{2}$

Master of Nursing Faculty of Medicine and Health Sciences ${ }^{1}$, Lecture Master of Nursing Faculty of Medicine and Health Sciences ${ }^{2}$ University of Muhammadiyah Yogyakarta, Ring Road Selatan, Bantul, Yogyakarta

(ady.irawan.am@gmail.com)

\begin{abstract}
ABSTRAK
Latar Belakang: HIV/AIDS menjadi salah salah satu tantangan sosial karena dampak penyakit ini yang begitu luas di masyarakat. Ketika seseorang terinfeksi virus HIV, sebagian besar dari mereka lebih banyak mengasingkan diri dari lingkungan sosial mereka serta mengalami gejala psikososial. Dukungan dari keluarga tentunya akan sangat membantu untuk mengurangi gangguan psikologis yang berkaitan dengan HIV/AIDS

Tujuan Penelitian: Penelitian ini bertujuan untuk mendeskripsikan bagaimana dukungan keluarga pada penderita HIV/AIDS.

Metode: Penelitian ini merupakan litetature review. Sumber penelitian diambil dari beberapa database, dengan kata kunci "family support on HIV/AIDS". Dari database Google Scholar ditemukan jurnal sejumlah 23,400, EBSCO ditemukan 323, NCBI ditemukan 16, dan ProQuest 693. Dari keseluruhan database hanya 11 yang memenuhi kriteria inklusi.
\end{abstract}

Hasil: Dukungan keluarga yang dipakai cukup luas dalam 11 artikel yang di review: dukungan penghargaan, dukungan informasi, dukungan emosi, dukungan pelayanan.

Kata kunci: mekanisme koping, hambatan keluarga, HIV/AIDS.

\section{ABSTRACT}

Background: HIV / AIDS is one of one of the social challenges due to the impact of this disease is so widespread in society. When a person is infected with HIV, most of them more alienated themselves from their social environment as well as experiencing symptoms of psychosocial. Support from the family will certainly help to reduce the psychological disorders related to HIV / AIDS

Objective: This study aimed to describe how the family support to people with HIV / AIDS.

Methods: This study is litetaturereview.Sources were taken from several databases with keywords "family support on HIV / AIDS". From the Google Scholar database found some 23,400 journals, EBSCO found 323, found NCBI 16 and 693. Of the overall database ProQuest only 11 met inclusion criteria.

Result: Family support is used widely enough in the 11 articles in the review: support awards, support information, emotionalsupport, support service.

Keyword: coping mechanisms, family constraints, HIV / AIDS. 
Avicenna Journal of Health Research. Vol 1 No 2. Oktober 2018 (44-53)

\section{PENDAHULUAN}

HIV/AIDS menjadi salah salah satu tantangan sosial karena dampak penyakit ini yang begitu luas di masyarakat (Izzawati \& Vahana, 2014; Rao, Ramapuram, Kotian, 2016). Orang dengan HIV/AIDS (ODHA) tidak hanya menghadapi tantangan perubahan pada fisiknya yang memiliki kecenderungan untuk semakin lemah setiap harinya, tetapi juga perubahan emosi atau psikologis yang tidak menentu. Sejak ditemukannya penyakit AIDS dan virus penyebabnya HIV, muncul dampak yang kompleks dalam masyarakat. Ketika seseorang terinfeksi virus HIV, sebagian besar dari mereka lebih banyak mengasingkan diri dari lingkungan sosial mereka serta mengalami gejala psikososial seperti: hidup stress,depresi, merasa kurang dukungan sosial dan perubahan perilaku mengemukakan bahwa penderita HIV/AIDS menghadapi situasi hidup dimana mereka sering menghadapi sendirinya kondisinya tanpa dukungan dari teman dan keluarga yang memberi dampak kecemasan, depresi, rasa bersalah dan pemikiran atau perilaku bunuh diri (Ronny 2012).

Menurut Pratama \& Sulistyarini (2012) menyatakan kasus HIV/AIDS menjadi sorotan dunia karena jumlahnya yang terus meningkat. Penderita AIDS di seluruh dunia mencapai lebih dari 12.000 orang. Di Indonesia, Kementrian Kesehatan Republik Indonesia melaporkan kasus HIV mengalami perningkatan menjadi 6.806 dimana 5.489 HIV dan 1.317 AIDS (Izzawati \& Vahana, 2014). Dukungan dari keluarga tentunya akan sangat membantu untuk mengurangi gangguan psikologis yang berkaitan dengan HIV/AIDS. Tersedianya dukungan positif yang diberikan oleh keluarga tentunya akan membuat seseorang yang teridentifikasi HIV dan AIDS menatap hidupnya ke depan dengan lebih positif, sehinggga dukungan positif yang diberikan oleh keluarga juga akan membuat dampak positif terhadap mekanisme koping pada penderita HIV/AIDS. Motivasi sangat besar pengaruhnya dalam kehidupan seseorang baik berupa motivasi ekstrinsik (dukungan orang tua, teman dan sebagainya) maupun motivasi intrinsic (dari individu sendiri). Dukungan social mempengaruhi kesehatan dan melindungi seseorang terhadap efek negative stress berat (Nursalam, 2007).

Amiya et al., (2014) mengatakan bahwa tidak ada pengaruh dukungan keluarga terhadap penderita HIV/AIDS karena dari awal mereka semenjak mengetahui hasilnya sudah mengalami depresi yang menyebabkan peningkatan stress yang membuat mereka depresi dan menyebabkan mereka me;lakukan bunuh diri. Dari latar belakang di atas bagaimana dukungan keluarga terhadap penderita HIV/AIDS? Untuk menjawab pertanyaan ini sebuah upaya dilakukan untuk meninjau dan merangkum secara sistematis hasil studi yang dipublikasikan mengenai pengaruh dukungan keluarga terhadap penderita HIV/AIDS. Tujuan utama dari tinjauan literatur ini adalah untuk memberikan tinjauan penelitian yang sistematis mengenai dampak pengaruh dukungan keluarga terhadap penderita HIV/AIDS. Dalam tinjauan ini, menilai kualitas metodologi penelitian yang diulas, tanpa menerapkan pembatasan mengenai negara, pengaturan kesehatan perawatan atau periode waktu. Pertanyaan utamanya adalah apakah pada dukungan keluarga mampu mempengaruhi penderita HIV/AIDS selama proses rehabilitasi atau pengobatan? Untuk menjawab pertanyaan ini, peneliti meninjau 
kembali karakteristik dukungan keluarga (yaitu jenis dukungan keluarga, pengaruh dukungan keluarga terhadap mekanisme koping dan hambatan dalam dukungan keluarga) dalam studi yang relevan, kualitas studi, dan keefektifan metode ini pada penderita HIV/AIDS.

\section{METODE PENELITIAN}

\section{Kriteria inklusi}

Kriteria inklusi berikut digunakan untuk pemilihan studi untuk literature review ini:

- Penelitian harus berkaitan dengan dukungan keluarga terhadap pasien HIV AIDS

- Penelitian ini harus memberikan informasi tentang dukungan keluarga terhadap pasien HIV AIDS

- Teks lengkap studi harus tersedia dalam bahasa Inggris dan bahasa Indonesia.

- Jurnal dicari mulai tahun 2013-2017

Kriteria eksklusi

Publikasi tidak asli seperti surat ke editor, abstrak saja, dan editorial.

Literature Search

Pencarian literatur dilakukan pada Desember 2017. Peneliti melakukan pencarian sumber data menggunakan beberapa database seperti NCBI, Ebsco, ProQuest dan Google Schoolar. Kata kunci yang digunakan adalah "family support on HIV/AIDS". Peneliti memberikan limitasi untuk pencarian jurnal terkait yaitu diantara tahun 2013-2017, dengan tujuan untuk mencari sumber valid yang tidak out of date dan sesuai perkembangan zaman.

Data Selection and Analysis

Pencarian jurnal dilakukan melalui database NCBI, Ebsco, ProQuest dan Google Schoolar lalu jurnal di ekstrak oleh peneliti secara indipenden. Judul dan abstrak jurnal yang disimpan dalam database internasional dicari dengan menggunakan kata kunci yang ada. jurnal ini di ambil dari database Google Shoolar, EBSCO, NCBI, ProQuest. Tiap database dicari dengan menggunakan kata kunci yang sama yaitu " Family Support HIV/AIDS". Dari database Google Scholar ditemukan jurnal sejumlah 23,400, EBSCO ditemukan 323, NCBI ditemukan 16, dan ProQuest 693. Dari keseluruhan database hanya 11 yang memenuhi kriteria inklusi. 
Tabel 1. Proses pencarian artikel

\begin{tabular}{|c|}
\hline Identification \\
\hline Screening \\
\hline Eligbility \\
\hline Include \\
\hline
\end{tabular}

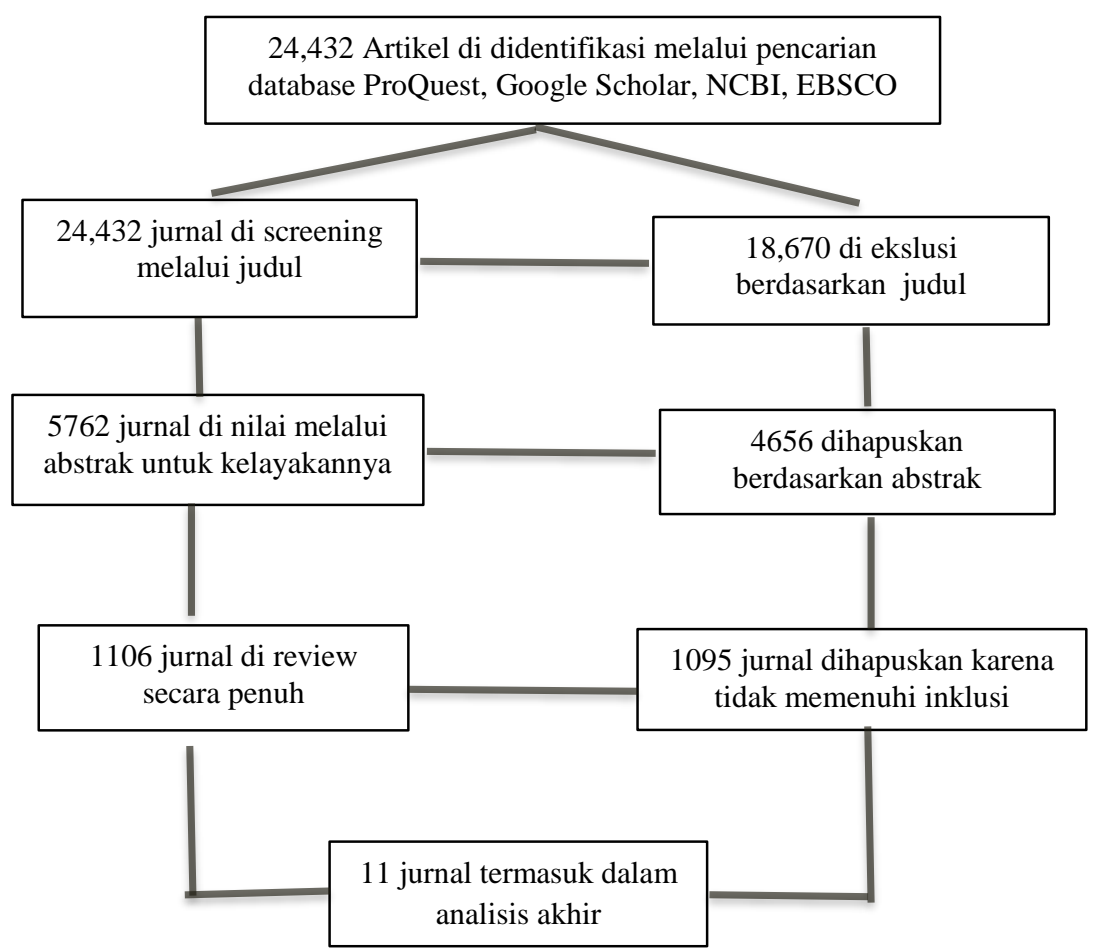

\section{HASIL DAN PEMBAHASAN}

Fokus utama dari literatur review ini adalah pada dukungan keluarga, dukungan keluarga terhadap mekanisme koping dan hambatan keluarga dalam memberi dukungan pada penderita HIV/AIDS. Untuk mengoptimalkan interpretasi ini, pertama-tama kta akan mengklarifikasi hasil temuan penelitian dari review 11 artikel. Pada hasil tentang pengaruh dukungan keluarga ada dua hasil,yang pertama ada pengaruh dukungan keluarga terhadap penderita HIV/AIDS (Pratama and Sulistyarini, 2012; Rao et al., 2016; Valeria et al., 2016,Qypi, 2017,), dan ada 1 jurnal yang tidak mendukung ada nya peningkaatan dukungan keluarga terhadap penderita HIV/AIDS (Amiya et al., 2014)

\section{Dukungan Keluarga}

Dukungan keluarga yang dipakai cukup luas dalam 11 artikel yang di review, antara lain: dukungan penghargaan (Pratama and Sulistyarini, 2012), dukungan informasi (Wounters et. al, 2016, Pratama and Sulistyarini,2012), dukungan emosi (Amiya et al., 2014; Masquillier et al., 2014; Pratama and Sulistyarini, 2012; Rao et al., 2016; Valeria et al., 2016) dan dukungan pelayanan (Kninght et. Al,2016).

\section{Dukungan Keluarga Terhadap Mekanisme Koping}

Ayer et al. (2016) mengatakan mekanisme koping penderita HIV/AIDS berupa merasa menunjukkan cinta dan kepedulian keluarga serta merasa bisa berbagi perasaan dengan keluarga. Mekanisme koping penderita HIV/AIDS sangat dipengaruhi oleh dukungan emosi dari keluarga (Qypi., 2017; Valeria et al., 2016; Pratama and Sulistyarini, 2012). Selain itu, Wouters et al. dan Knight et al., 
(2016) mengatakan memberikan dukungan informasi dan dukungan pelayanan adalah fokus utama dalam penanganan mekanisme koping. Xu et al. (2017), Rao et al. (2016) dan Masquillier et al. (2014) mengatakan kombinasi dari pemberian dukungan emosi dan pelayanan akan sangat membantu pasien. Pratama and Sulistyarini (2012) dan Izzati (2014) menambahkan dukungan instrumental dan dukungan informatif adalah bentuk dukungan keluarga terhadap mekanisme koping.

\section{Hambatan Keluarga Dalam Memberikan Dukungan}

Beberapa hambatan dalam memberikan dukungan kepada penderita HIV/AIDS antara lain tingkat pengetahuan (Masquillier et al., 2014), tingkat pendidikan dan stigma (Qypi., 2017; Xu et al., 2017; Ayer et al., 2016), perilaku menolak dari pasien sendiri (Wouters et al., 2016), perasaan ditolak oleh orang lain (Valeria et al., 2016), keadaan emosi yang berubah-ubah (Rao et al., 2016; Izzati, 2014; Amiya et al., 2014), serta beberapa pasien yang enggan untuk tinggal dengan keluarga kerena diangap ancaman untuk menular (Knight et al., 2016).

\section{Tabel 2. Studi Karakteristik Dukungan Keluarga Pada Penderita HIV AIDS}

\begin{tabular}{|c|c|c|c|c|}
\hline Source/ Autors & Aim & Design & Sample & Result \\
\hline $\begin{array}{l}\text { Amiya et al., } \\
2014\end{array}$ & examine factors & $\begin{array}{l}\text { Cross- } \\
\text { Section } \\
\text { al }\end{array}$ & $\begin{array}{l}322 \\
\text { Adult }\end{array}$ & $\begin{array}{l}\text { HIV/AIDS often } \\
\text { triggering profound } \\
\text { detrimental impacts } \\
\text { on quality of life, } \\
\text { treatment } \\
\text { adherence, disease } \\
\text { progression, and } \\
\text { mortality. Yet the } \\
\text { psychosocial } \\
\text { factors contributing } \\
\text { to these psychiatric } \\
\text { comorbidities } \\
\text { remain } \\
\text { underexplored, } \\
\text { particularly in the } \\
\text { developing country. }\end{array}$ \\
\hline Ayer et al., 2016 & $\begin{array}{l}\text { this study was conducted } \\
\text { to examine the } \\
\text { association between } \\
\text { perceived family } \\
\text { support and regular clinic } \\
\text { attendance and to assess } \\
\text { factors associated with } \\
\text { regular clinic } \\
\text { attendance } \\
\text { antiretroviral pills pick- } \\
\text { up among HIV-positive } \\
\text { individuals in Nepal. }\end{array}$ & $\begin{array}{l}\text { Cross- } \\
\text { Section } \\
\text { al }\end{array}$ & $\begin{array}{l}423 \text { HIV- } \\
\text { positive } \\
\text { people }\end{array}$ & $\begin{array}{l}\text { HIV-positive } \\
\text { individuals are } \\
\text { more likely to } \\
\text { attend the clinics } \\
\text { regularly when they } \\
\text { receive high family } \\
\text { support }\end{array}$ \\
\hline $\begin{array}{l}\text { Wouters et al., } \\
2016\end{array}$ & $\begin{array}{l}\text { to extend the current } \\
\text { literature } \\
\text { by simultaneously } \\
\text { investigating the impact }\end{array}$ & $\mathrm{RCT}$ & $\begin{array}{l}435 \\
\text { patients }\end{array}$ & $\begin{array}{l}\text { demonstrate that the } \\
\text { familial context in } \\
\text { which a person with } \\
\text { HIV on ART }\end{array}$ \\
\hline
\end{tabular}


Avicenna Journal of Health Research. Vol 1 No 2. Oktober 2018 (44-53)

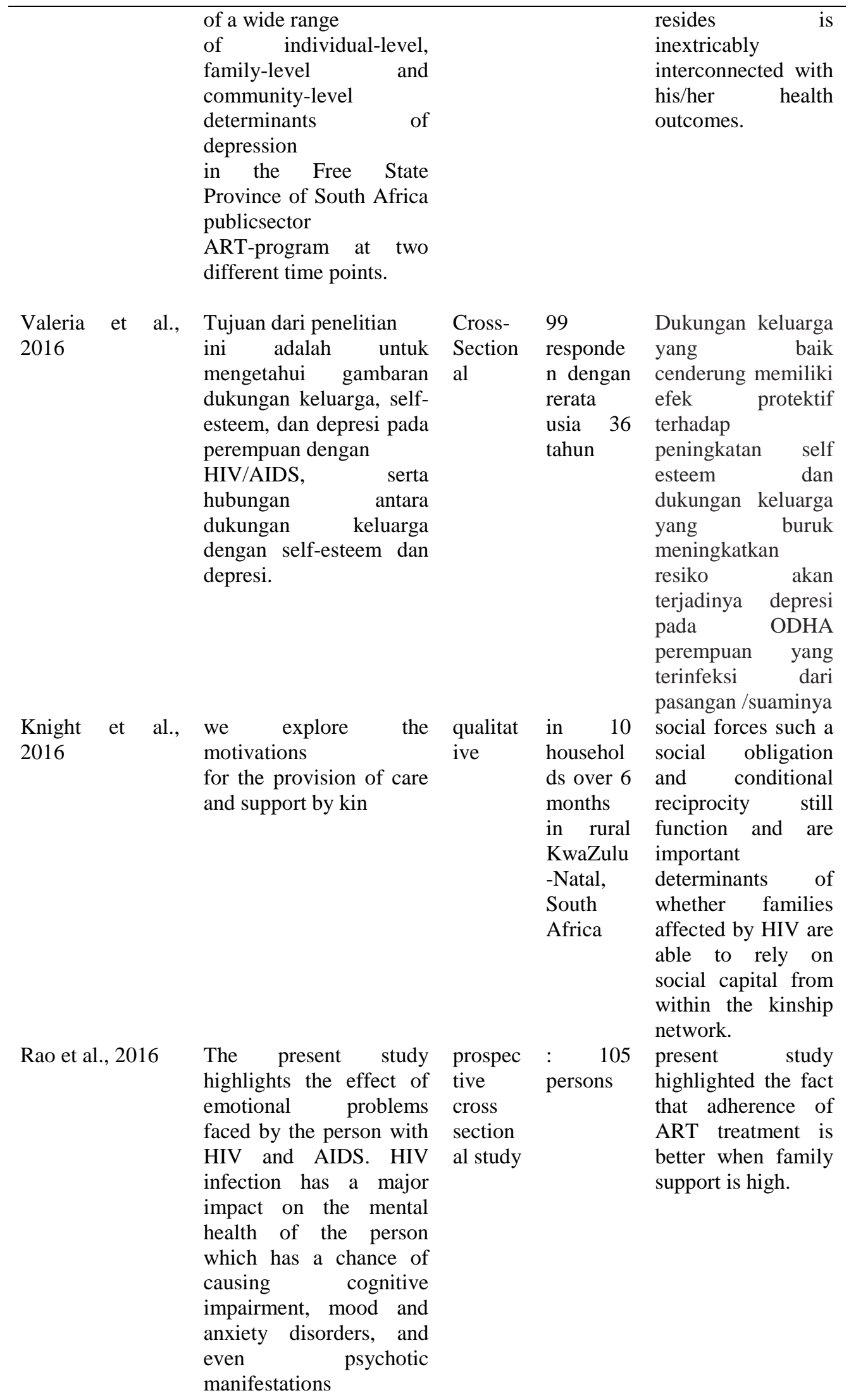


Avicenna Journal of Health Research. Vol 1 No 2. Oktober 2018 (44-53)

Masquillier et al., 2014

Xu et al., 2017

Pratama

and

Sulistyari

ni, 2012
In

this regard, the dual aim of this article is (1) to analyze the influence of a peer adherence support (PAS) intervention and the

family environment on the state of hope in PLWHA and (2) to investigate the interrelationship between the two determinants.

identifies the family

support enjoyed and discrimination faced by people infected with HIV and examines the effect they have on patients' quality of life (QOL) as they undergo ART in China.

this study is to find out the relationship between family effect on the intention of depression on HIV/AIDS victim.

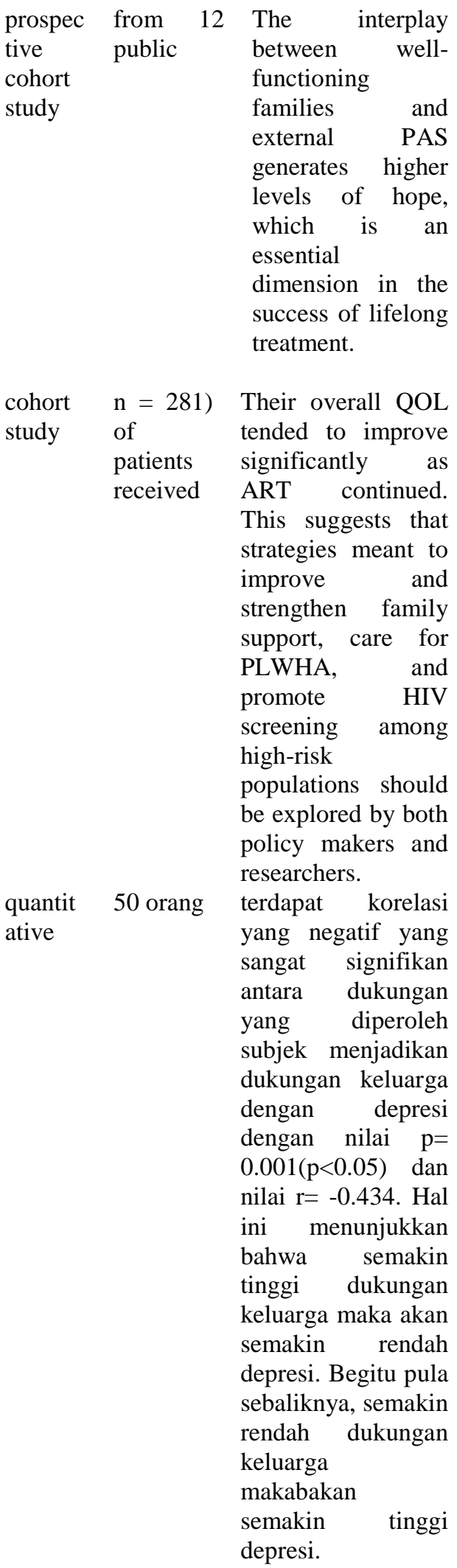


Avicenna Journal of Health Research. Vol 1 No 2. Oktober 2018 (44-53)

\begin{tabular}{|c|c|c|c|c|}
\hline Qypi., 2017 & $\begin{array}{l}\text { The main purpose of this } \\
\text { study is to show how } \\
\text { important is the family } \\
\text { support for people with } \\
\text { HIV / AIDS. }\end{array}$ & $\begin{array}{l}\text { qualitat } \\
\text { ive } \\
\text { method }\end{array}$ & $\begin{array}{l}10 \\
\text { interview } \\
\mathrm{s}\end{array}$ & $\begin{array}{l}\text { The results showed } \\
\text { that the support } \\
\text { provided by the } \\
\text { family is a } \\
\text { necessity for a } \\
\text { person with HIV / } \\
\text { AIDS, because they } \\
\text { feel supported from } \\
\text { the family and } \\
\text { accepted as a } \\
\text { member of it, valid } \\
\text { and non- } \\
\text { discriminated. }\end{array}$ \\
\hline Izzati, 2014 & $\begin{array}{l}\text { This study aims to } \\
\text { determine relationships - } \\
\text { relationships with family } \\
\text { support coping } \\
\text { mechanisms of patients } \\
\text { with HIV / AIDS in fife } \\
\text { Poly RS Achmad } \\
\text { Mochtar Bukittinggi }\end{array}$ & $\begin{array}{l}\text { Cross } \\
\text { Section } \\
\text { al }\end{array}$ & $\begin{array}{l}40 \\
\text { Sampel }\end{array}$ & $\begin{array}{l}\text { studies in humans } \\
\text { showed that as } \\
\text { many ( } 52.5 \% \text { ) of } \\
\text { respondents obtain } \\
\text { optimal support } \\
\text { while the family ( } \\
47.5 \text { ) } \\
\text { respondents who } \\
\text { get minimal family } \\
\text { support. ( } 55 \%) \text { of } \\
\text { respondents have an } \\
\text { adaptive coping } \\
\text { mechanism, while ( } \\
45 \% \text { of } \\
\text { respondents have a } \\
\text { maladaptive coping } \\
\text { mechanisms . }\end{array}$ \\
\hline
\end{tabular}

Beberapa penelitian telah dilakukan untuk mengetahui pengaruh dukungan keluarga terhadap penderita HIV/AIDS yang mendukung pengaruh dukungan keluarga terhadap penderita HIV/AIDS sejumlah 10 penelitian (Ayer et al., 2016, Wouters et al., 2016, Valeria et al., 2016, Knight et al., 2016, Rao et al., 2016, Masquillier et al., 2014, Xu et al., 2017, Pratama and Sulistyarini, 2012, Abbott et al., 2001, Izzati, 2014).

Ayer et al., 2016 mengatakan Merasa menunjukkan cinta dan kepedulian keluarga, Merasa bisa berbagi perasaan dengan keluarga. Tapi hambatan keluarga yang mempengaruhi adalah tingkat pendidikan dan stigma. Pengaruh dalam mekanisme kopingnya tidak djelaskan secara rinci hanya mengalami perubahan dalam pengobatan. Wouters et al., 2016 mengatakan memberikan dukungan informasi dan hambatannya adalah perilaku menolak dari pasien sendiri, sedangkan pengaruh pada pasiennya sendiri adalah perubahan emosional. Valeria et al., 2016 mengatakan memberikan dukungan emosi mempengaruhi pasien dan hambatan yang dialami pasien secara emosional tentang perasaan ditolak,untuk mekanisme koping mereka membaik setelah diberi dukungan emosional, Knight et al., 2016 mengatakan dukungan pelayanan adalah fokus utama dalam penanganan ini sedangkan hambatannya adalah beberapa pasien yang enggan untuk tinggal dengan keluarga kerena diangap ancaman untuk menular. 
Setelah diberi dukungan mekanisme koping mereka belum tampak secara jelas membaik atau berubah. Rao et al., 2016 mengatakan pemberian dukungan emosi dan pelayanan akan sangat membantu pasien sedangkan hambatan yang dialami dalam diri pasien sendiri berupa emosi yang berubah-ubah, setelah diberi dukungan beberapa pasien mengalami perubahan emosi yang menjadi membaik. Masquillier et al., 2014 mengatakan dukungan emosi yang utama tetapi hambatan dalam tingkat pengetahuan sangatmempenaruhi nya. Tapi dukungan emosional membuat penderita memiliki harapan utnuk menjalankan aktifitas mereka sehari hari.

Xu et al., 2017 mengatakan dukungan pelayanan yang utama tapi hambatan utamanya adalah stigma yang ada di masyarakat dan pasien sendiri, tetapi koping pasien yang disediakan layanan mulai membaik dengna mau ikut pengibatan rutin. Pratama and Sulistyarini, 2012 mengatakan dukungan instrumental, dukungan informatif, dukungan secara emosional adalh yag penting tetapi habatan yang terlihat adalah depresi pasien saat menerima kenyataan soal penyakt dan koping mereka berubah menjadi depresi dan sebagian yang menerima perlakuan perawatan menjadi baik dan mau menerima kenyatan. Abbott et al., 2001 mengatakan dukungan emosional dan hambatan utamanya adalah stigma masyarakat, peruahan koping adalah kondisi kejiwaan pasien yang membaik. Izzati, 2014 mengatakan dukungan informasi adalah hal utama dalam keluarga dan penderita sedangkan hambatan yang terlihat adalah emosional atau kejiwaan penderita itusendiri. Tapi setelah diberi informasi mereka mulai mau berobat dan berubah.

Ada satu yang tidak mendukung (Amiya et al., 2014). Amiya et al., 2014 mengatakaan mempelihatkan dukungan emosional adlah hal yang utama tapi hambatan tentang stigma dan pengaruh emosional pasien sendri mempengaruhi sehingga dukungan keluarga tidak berdampak bnayak. Meskipiun sebagian besar jurnal penelitan mendukung pengaruh dukungan keluarga terhadap penderita HIV/AIDS, tetapi tidak semua aspek 4 (dukungan emosi, dukungan informasi, dukungan pelayanan, dukungan penghargaan), ada pengaruh dukungan keluarga yang bahkan tidak terlalu signifikan peningkatannya. Paling terlihat hasil dukungan keluarga melalui aspek emosionalnya (Amiya et al., 2014; Valeria et al., 2016; Rao et al., 2016; Pratama and Sulistyarini, 2012; Qypi, 2017).

Pertanyaan yang muncul adalah apakah kita bisa memunculkan penilian pada keempat aspek untuk pengaruh dukungan keluarga terhadap penderita HIV/AIDS? Jawaban atas pertanyaan ini bisa menjadi landasan bagi penelitian lebih lanjut untuk mengarahkan kepada keluarga tentang pentingnya dukungan keluarga terhadap penderita HIV/AIDS dalam proses pengobatan.

\section{SIMPULAN DAN SARAN}

Tinjauan dalam literatur review penelitian ini mendapatkan hasil dukungan keluarga mempengaruhi penderita HIV/AIDS secara emosional utamanya. Tetapi belum dapat dipastikan secara tepat karena ini hanya baru dari penyampain penderita saja dan keluarga. Belum ada alat ukur atau instrument khusus untuk mengukur tingkat pengaruh dukungan keluarga. Hal ini dikarenakan belum ada 
penelitian terkait yang membuktikan tentang instrument yang sesuai untuk penderita HIV/AIDS.

Selain itu hasil dari penelitian terkait instrument dan scenario yang digunakan juga mempengaruhi keterbatasan. Dengan demikian dibutuhkan usaha dan perhatian khusus untuk merancang instrument dan scenario khusus untuk mengukur pengaruh dukungan keluarga terhadap penderita HIV/AIDS selama proses penyakit dan rehabilitasinya.

\section{DAFTAR PUSTAKA}

Amiya, R.M., Poudel, K.C., Poudel-Tandukar, K., Pandey, B.D., Jimba, M., 2014. Perceived Family Support, Depression, and Suicidal Ideation among People Living with HIV/AIDS: A Cross-Sectional Study in the Kathmandu Valley, Nepal. PLoS ONE 9, e90959. https://doi.org/10.1371/journal.pone.0090959

Ayer, R., Kikuchi, K., Ghimire, M., Shibanuma, A., Pant, M.R., Poudel, K.C., Jimba, M., 2016. Clinic Attendance for Antiretroviral Pills Pick-Up among HIVPositive People in Nepal: Roles of Perceived Family Support and Associated Factors. PLOS ONE 11, e0159382. https://doi.org/10.1371/journal.pone.0159382

Izzati, W., 2014. Hubungan Dukungan Keluarga dengan Mekanisme Koping Pasien HIV/AIDS di Poli Serunai RSAM Bukittinggi 2013. 'AFIYAH 1.

Knight, L., Hosegood, V., Timæus, I.M., 2016. Obligation to family during times of transition: care, support and the response to HIV and AIDS in rural South Africa. AIDS Care 28, 18-29. https://doi.org/10.1080/09540121.2016.1195486

Masquillier, C., Wouters, E., Mortelmans, D., le Roux Booysen, F., 2014. Families as catalysts for peer adherence support in enhancing hope for people living with HIV/AIDS in South Africa. J. Int. AIDS Soc. 17. https://doi.org/10.7448/IAS.17.1.18802

Pratama, P.A., Sulistyarini, R.I., 2012. Dukungan Keluarga Dan Depresi Pada Penderita Hiv/Aids Di Yogyakarta. Psikologika J. Pemikir. Dan Penelit. Psikol. 17.

Rao, M.A., Ramapuram, J., Kotian, S.S., 2016. Assessment of Emotional Problems faced by People Living with HIV/AIDS and to study the role of family support and role of a counsellor to manage the Emotional Problems. Imp. J. Interdiscip. Res. 2.

Valeria, J., Surilena, S., Budiman, Y., Djauzi, S., Indah, H., 2016. Family support is not a risk factor of negative self-esteem in HIV/AIDS women. Universa Med. 34, 61-67.

Wouters, E., Masquillier, C., le Roux Booysen, F., 2016. The Importance of the family: a longitudinal study of the predictors of depression in HIV patients in South Africa. AIDS Behav. 20, 1591-1602.

Xu, J.-F., Ming, Z.-Q., Zhang, Y.-Q., Wang, P.-C., Jing, J., Cheng, F., 2017. Family support, discrimination, and quality of life among ART-treated HIV-infected patients: a two-year study in China. Infect. Dis. Poverty 6. https://doi.org/10.1186/s40249-017-0364-5

Qypi K, 2017. The importance of family support for individuals with HIV/AIDS: Master $2^{\text {nd }}$ Year, Social Services Departement,"Aleksander Xhuvani" University, Elbasan, Albania. https: // doi .org/10.5281 /zenodo.32.1.337 